\title{
Luteinizing Hormone-Releasing Hormone Receptor-Targeted Chemotherapy Using AN-152
}

\author{
Günter Emons $^{a} \quad$ Herbert Sindermann $^{b}$ Jürgen Engel ${ }^{b}$ Andrew V. Schally ${ }^{c}$ \\ Carsten Gründker ${ }^{a}$ \\ ${ }^{a}$ Department of Gynecology and Obstetrics, Georg August University, Göttingen, and ${ }^{\text {b } / t e r n a ~ Z e n t a r i s ~ G m b H, ~}$ \\ Frankfurt, Germany; ' Veterans Affairs Medical Center, Miami, Fla., USA
}

\section{Key Words}

Luteinizing hormone-releasing hormone - AN-152 • Gonadotropin-releasing hormone $\cdot$ Receptor-targeted therapy

\begin{abstract}
The luteinizing hormone-releasing hormone ( $\mathrm{LHRH}$; also known as gonadotropin-releasing hormone) receptor can be utilized for targeted chemotherapy with cytotoxic LHRH analogues such as AN-152, in which doxorubicin is linked to [D-Lys $\left.{ }^{6}\right]$ LHRH. Our studies demonstrate receptor-mediated actions of the cytotoxic LHRH analogue AN-152 in LHRH receptor-positive endometrial and ovarian tumors in vivo. Intravenous administration of AN-152 is far less toxic and inhibits the growth of $\mathrm{LHRH}$ receptor-positive tumors better than equimolar doses of the cytotoxic agent doxorubicin. AN-152 has no antitumor activity in LHRH receptor-negative cancers. This provides evidence for the principle of targeted cytotoxic chemotherapy to tumor cells expressing LHRH receptors. In addition, we were able to show that LHRH binding sites were only slightly reduced after AN-152 treatment. Therefore, repeated therapy is considered to be possible. The majority (80\%) of human endometrial and ovarian cancers and about $50 \%$ of breast cancers express LHRH receptors. In addition, apart from reproductive organs, which are
\end{abstract}

normally removed during surgical therapy, other organs and hematopoietic stem cells do not express LHRH receptors. Thus, cytotoxic LHRH analogues such as AN-152 appear to be suitable drugs for a more efficacious and less toxic targeted chemotherapy for endometrial and ovarian cancers. A recently finished phase I study assessed the dose limitations, maximum tolerated dose and pharmacokinetics of AN-152 given once every 3 weeks in patients with gynecological and breast cancers. A phase II study was started in January 2008.

Copyright $\odot 2009$ S. Karger AG, Basel

\section{Background}

Endometrial cancer is the most frequent malignant gynecological tumor in the Western world. In most cases, it is diagnosed at an early stage when surgery alone or in combination with radiotherapy can achieve high cure rates. However, steroid receptor-negative tumors in elderly women or at advanced stages are rarely cured [1-3]. Ovarian cancer is less frequent than endometrial cancer, but it is the most common cause of death from gynecological neoplasms [4]. Effective regimens for surgery and first-line cytotoxic chemotherapy are established, but in advanced or relapsed cases, curative or palliative treat- 


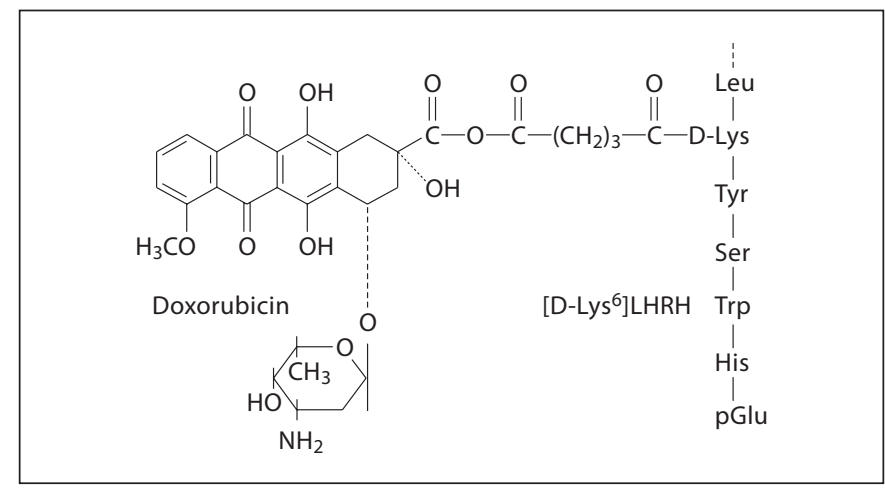

Fig. 1. LHRH analogue AN-152 (cytotoxic doxorubicin covalently linked to LHRH agonist [D-Lys $\left.\left.{ }^{6}\right] \mathrm{LHRH}\right)$.

ments with long-term efficacy remain to be established [5-7]. In both endometrial and ovarian cancer, new therapeutic strategies are required that are well tolerated and more efficacious. Cytotoxic drugs are used as single agents or as combinations of several antitumor agents with different mechanisms of action. This chemotherapy is limited by its toxicity to normal cells. A more selective delivery of the cytotoxic agents to the tumor cells would allow the use of increased doses and would reduce the toxicity to normal cells.

\section{Luteinizing Hormone-Releasing Hormone Receptor Expression}

More than $80 \%$ of human ovarian and endometrial cancers and about $50 \%$ of breast cancers express receptors for luteinizing hormone-releasing hormone (LHRH; also known as gonadotropin-releasing hormone) [8, 9]. Apart from pituitary cells and reproductive organs (ovaries, fallopian tubes and uterus), which are normally removed during surgical therapy of ovarian or endometrial cancer, other organs and hematopoietic stem cells do not express LHRH receptors [10]. Thus, these receptors could be utilized for targeted therapy to improve antitumor effects and reduce side effects compared with systemic conventional cytotoxic chemotherapy [11].

\section{LHRH Receptor-Targeted Chemotherapy}

Cytotoxic LHRH analogues have been developed, where a cytotoxic agent is covalently linked to an LHRH analogue [12]. These LHRH analogues that are covalent- ly coupled to cytotoxic radicals bind specifically to LHRH receptors with their peptide moiety and act as chemotherapeutic agents after internalization of the ligand-receptor complex or at the membrane of cancer cells [12]. Thus, these cytotoxic LHRH analogues should selectively affect those cells that express LHRH receptors and would exert fewer side effects than unconjugated cytotoxic agents [12]. We were able to demonstrate that such a cytotoxic LHRH analogue, AN-152 (fig. 1), in which doxorubicinislinked totheagonistcarrier[D-Lys ${ }^{6}$ LHRH, is selectively internalized in human ovarian or endometrial cancer cell lines that express LHRH receptors. After internalization of $\mathrm{AN}-152$, doxorubicin is cleaved from LHRH and accumulates in the nucleus. This uptake of AN-152 could be competitively inhibited by an excess of an LHRH agonist. In cancer cell lines that do not express LHRH receptors, no intracellular accumulation of AN152 could be detected [13]. In 3 out of 4 LHRH receptorpositive cell lines, AN-152 was more effective than doxorubicin in inhibiting cell proliferation in vitro. These results suggest a selective receptor-mediated action of AN-152 in LHRH receptor-positive cell lines and encouraged us to study the efficacy of AN-152 in vivo [10]. LHRH receptor-positive HEC-1B endometrial cancers and OVCAR-3 ovarian cancers, as well as LHRH receptor-negative SK-OV-3 ovarian cancers were xenografted into nude mice. Animals bearing these tumors subcutaneously were injected intravenously with saline solution (control), AN-152 or doxorubicin at equimolar doses. The tumor volumes of LHRH receptor-positive HEC-1B and OVCAR-3 cancers were reduced significantly 1 week after treatment with $\mathrm{AN}-152$ at $700 \mathrm{nmol} / 20 \mathrm{~g}$ or at 300 $\mathrm{nmol} / 20 \mathrm{~g}$. No toxic side effects were observed. Treatment with $\left[\mathrm{D}-\mathrm{Lys}^{6}\right] \mathrm{LHRH}$ alone showed no significant effects on tumor volume. Treatment with doxorubicin arrested tumor growth but did not reduce tumor volume. Doxorubicin at $700 \mathrm{nmol} / 20 \mathrm{~g}$ caused a high mortality rate, and at $300 \mathrm{nmol} / 20 \mathrm{~g}$, it caused a loss of body weight but no deaths occurred. The growth of LHRH receptor-negative SKOV-3 cancers was not affected by AN-152. Thus, the cytotoxic LHRH analogue, AN-152, is more effective and less toxic than the cytotoxic radical doxorubicin on LHRH receptor-positive tumors [10]. In addition, we found that normal human nonreproductive tissues, hematopoietic stem cells and vaginal tissue did not express LHRH receptors [10]. It was only in the human ovary, endometrium, myometrium, fallopian tube and cervix, i.e. tissues derived from the müllerian epithelium, that expression of LHRH receptors was detected [10]. The ovaries, fallopian tubes and uterus are removed during cura- 


\section{Internalization of AN-152 induces MDR-1-independent apoptosis}

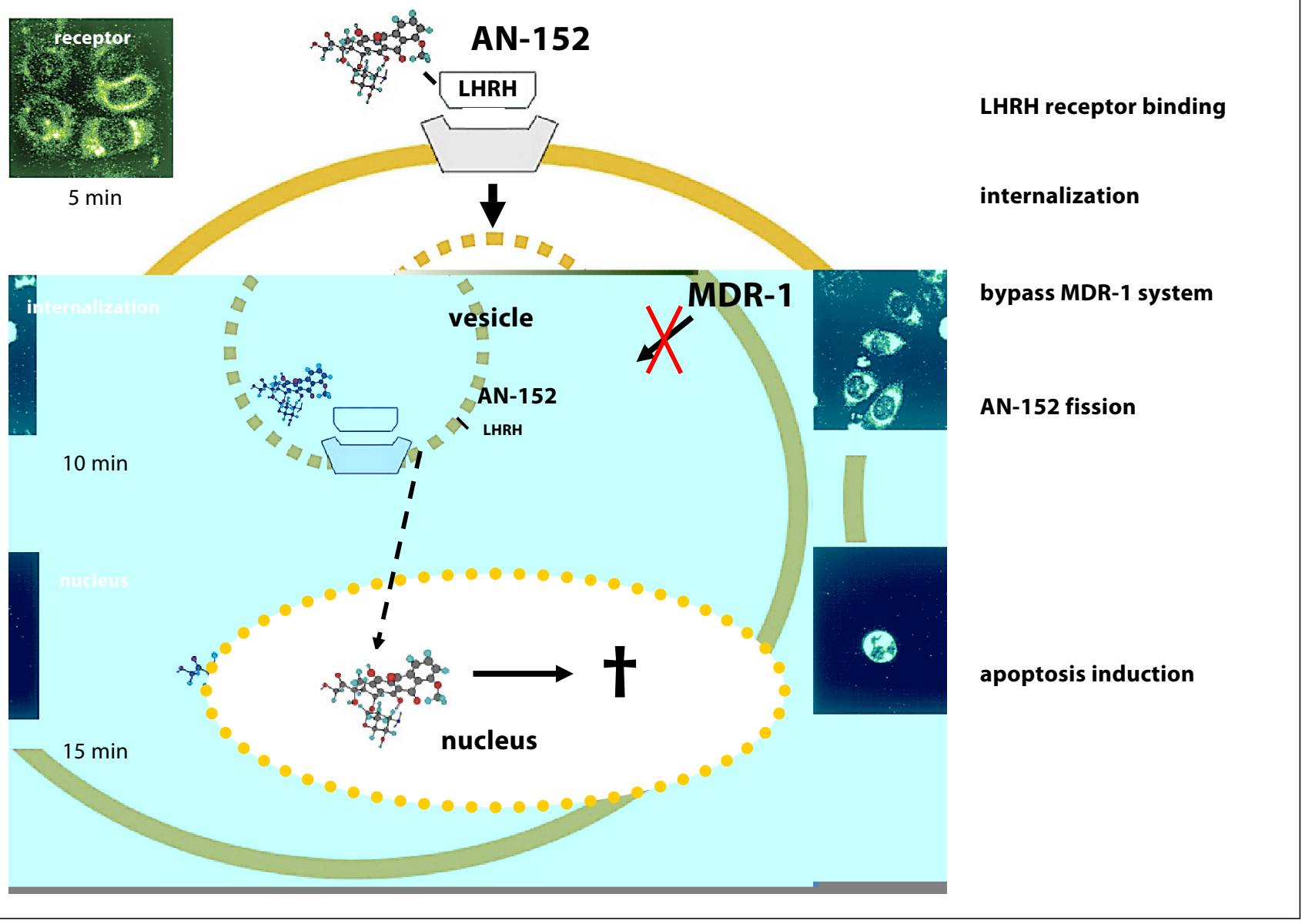

Fig. 2. Internalization of the cytotoxic LHRH analogue AN-152 induces multidrug resistance gene (MDR-1)-independent apoptosis. After receptor binding, the AN-152/LHRH receptor complex is internalized via coated vesicles bypassing the multidrug resistance-1 system. Thereafter, AN-152 is split and free doxorubicin is accumulated within the nucleus, inducing apoptosis. AN-152 and doxorubicin are autofluorescent at an excitation wave length of $488 \mathrm{~nm}$. Detection of AN-152 and doxorubicin was performed using laser scanning microscopy [13]. tive surgery of ovarian or endometrial cancer. Even if they are not removed due to the advanced stage of disease, it would not be harmful if they were affected by AN152 therapy. Therefore, AN-152 appears to be a suitable drug for a more efficacious and less toxic targeted chemotherapy for endometrial and ovarian cancers [10]. LHRH analogues bearing a more potent cytotoxic radical like 2pyrrolinodoxorubicin might be even more efficacious than AN-152 [10, 12].

In a recent study, we were able to demonstrate that the AN-152-induced apoptosis in human endometrial, ovarian and breast cancer cell lines is independent of the mul- tidrug resistance- 1 system $[14,15]$. Because of the LHRH receptor-mediated entry of AN-152 into ovarian and endometrial cancer cells, AN-152 may overcome chemoresistance, which is a major drawback of systemic therapy of these malignancies by anthracyclines $[14,15]$ (fig. 2).

\section{Clinical Trials}

In a clinical phase I trial, the toxicity of AN-152 was assessed in patients with ovarian, fallopian tube, endometrial and breast cancers, who were refractory to stan- 
dard therapy. Using an escalating dose schedule, doses of 160 and $267 \mathrm{mg} / \mathrm{m}^{2} \mathrm{AN}-152$ (equivalent to 46 and $77 \mathrm{mg} /$ $\mathrm{m}^{2}$ doxorubicin) were found to be well tolerated. Even at the $267 \mathrm{mg} / \mathrm{m}^{2}$ dose, hematological toxicity was low (no grade III and IV thrombocytopenia, 26\% grade III neutropenia, $11 \%$ grade IV neutropenia) without growth factor support. Alopecia occurred only in 31\% (grade I) and $23 \%$ (grade II). Other nonhematological side effects were mild. Considering the fact that patients had already received several other cytotoxic regimes before, the tolerability of AN-152 is promising. Though not the aim of a phase I trial, 3 of 13 patients treated with 160 or $267 \mathrm{mg} /$ $\mathrm{m}^{2} \mathrm{AN}-152$ had an objective response (complete normalization of pathological CA125 levels; partial remission of liver metastasis, and complete disappearance of lymph node metastasis) and 3 other patients had stable disease (stable hepatic metastasis; minor response in spleen metastasis, and stable spleen metastasis) [Emons et al., in press]. These results encouraged the Study Group of the 'Arbeitsgemeinschaft Gynäkologische Onkologie' to commence a phase II clinical trial in patients with ovarian cancer refractory to carboplatin and paclitaxel or with disseminated endometrial cancer. LHRH receptor expression is centrally assessed by immunohistochemistry in our laboratory. The dose of $267 \mathrm{mg} / \mathrm{m}^{2} \mathrm{AN}-152$ will be used.

\section{Acknowledgement}

This work was supported by the Deutsche Krebshilfe - Dr. Mildred Scheel Stiftung.

\section{References}

1 Emons G, Ortmann O, Schulz KD, Schally AV: Growth-inhibitory actions of analogues of luteinizing hormone releasing hormone on tumor cells. Trends Endocrinol Metab 1997;8:355-362.

$\checkmark 2$ Ho MN, Delgado CH, Owens GA, Steller MA: Insulin-like growth factor-II participates in the biphasic effect of a gonadotropin-releasing hormone agonist on ovarian cancer cell growth. Fertil Steril 1997;67:870 876.

$>3$ Emons G, Müller V, Ortmann O, Schulz KD: Effects of LHRH-analogues on mitogenic signal transduction in cancer cells. J Steroid Biochem Mol Biol 1998;65:199-206.

-4 Imai A, Takagi A, Horibe S, Takagi H, Tamaya T: Evidence for tight coupling of gonadotropin-releasing hormone receptor to stimulated Fas ligand expression in reproductive tract tumors: possible mechanism for hormonal control of apoptotic cell death. J Clin Endocrinol Metab 1998;83:427-431.

$>5$ Imai A, Takagi A, Horibe S, Takagi H, Tamaya T: Fas and Fas ligand system may mediate antiproliferative activity of gonadotropinreleasing hormone receptor in endometrial cancer cells. Int J Oncol 1998;13:97-100.
-6 Yin H, Cheng KW, Hwa HL, Peng C, Auersperg N, Leung PC: Expression of the messenger RNA for gonadotropin-releasing hormone and its receptor in human cancer cell lines. Life Sci 1998;62:2015-2023.

7 Seppala M, Wahlstrom T: Identification of luteinizing hormone-releasing factor and alpha subunit of glycoprotein hormones in ductal carcinoma of the mammary gland. Int J Cancer 1980;26:267-268.

$>8$ Gründker C, Günthert AR, Westphalen S, Emons G: Biology of the gonadotropin-releasing hormone system in gynecological cancers. Eur J Endocrinol 2002;146:1-14.

$>9$ Fekete M, Wittliff JL, Schally AV: Characteristics and distribution of receptors for [D$\left.\mathrm{TRP}^{6}\right]$-luteinizing hormone-releasing hormone, somatostatin, epidermal growth factor, and sex steroids in 500 biopsy samples of human breast cancer. J Clin Lab Anal 1989;3:137-147.

$>10$ Gründker C, Völker P, Griesinger F, Ramaswamy A, Nagy A, Schally AV, Emons G: Antitumor effects of the cytotoxic luteinizing hormone-releasing hormone analog AN-152 on human endometrial and ovarian cancers xenografted into nude mice. Am J Obstet Gynecol 2002;187:528-537.

11 Schally AV: Luteinizing hormone-releasing hormone analogs: their impact on the control of tumorigenesis. Peptides 1999;20: 1247-1262.
12 Schally AV, Nagy A: Cancer chemotherapy based on targeting of cytotoxic peptide conjugates to their receptors on tumors. Eur J Endocrinol 1999;141:1-14.

13 Westphalen S, Kotulla G, Kaiser F, Krauss W, Werning G, Elsasser HP, Nagy A, Schulz KD, Gründker C, Schally AV, Emons G: Receptor mediated antiproliferative effects of the cytotoxic LHRH agonist AN-152 in human ovarian and endometrial cancer cell lines. Int J Oncol 2000;17:1063-1069.

14 Günthert AR, Gründker C, Bongertz T, Schlott T, Nagy A, Schally AV, Emons G: Internalization of cytotoxic analog AN-152 of luteinizing hormone-releasing hormone induces apoptosis in human endometrial and ovarian cancer cell lines independent of multidrug resistance-1 (MDR-1) system. Am J Obstet Gynecol 2004;191:1164-1172.

15 Günthert AR, Gründker C, Bongertz T, Nagy A, Schally AV, Emons G: Induction of apoptosis by AN-152, a cytotoxic analog of luteinizing hormone-releasing hormone (LHRH), in LHRH-R positive human breast cancer cells is independent of multidrug resistance1 (MDR-1) system. Breast Cancer Res Treat 2004;87:255-264. 